\title{
Overview of FY 2001 federal budget request
}

The Clinton Administration's budget for fiscal year (FY) 2001 proposes a $\$ 2.9$ billion science and technology initiative, increasing federal research spending by $7 \%$. And, although it features nonbiological programs such as the National Nanotechnology Initiative somewhat at the expense of biomedical research, the intent is to "restore the balance between health care research and other scientific disciplines," says White House Science Advisor Neal Lane. Nonetheless, the budget boosts fund-

\section{The biological sciences component of the NSF overall budget totals nearly \$511 million, a $23 \%$ increase over the past year.}

ing for many federal R\&D programs, including biomedical research, and offers several initiatives with aims that overlap with those of the biotechnology industry.

For instance, the FY 2001 budget proposes a $\$ 93$ million initiative in $R \& D$ with the long-term goal of tripling US use of "biobased products and bioenergy" by 2010. This initiative mainly involves programs within the US Department of Agriculture (USDA; Washington, DC) and the Department of Energy (DOE; Germantown, MD). A major goal is to make biomass a viable competitor to fossil fuels as an energy source and chemical feedstock.

The administration proposals also seek to bolster federal spending on genomics research sponsored by several agencies and departments, particularly the National Institutes of Health (NIH; Bethesda, MD), DOE, and USDA. The administration budget for NIH requests $\$ 18.8$ billion overall, which is an increase of $\$ 1.0$ billion, or $5.6 \%$, over the previous year. Besides supporting genomics research and reinvigorated clinical research, NIH last year began supporting a Biomedical Information Science and Technology Initiative (BISTI) that also involves other federal agencies. BISTI funds are slated to grow from $\$ 110$ million to $\$ 147$ million.

The budget proposes $\$ 4.573$ billion for the National Science Foundation (NSF;
Arlington, VA), a \$675 million increase over the previous year. The biological sciences component of the NSF overall budget totals nearly \$511 million, a 23\% increase over the past year. An important component of the biological sciences at NSF is the expanded biocomplexity initiative, which will receive $\$ 136$ million. Moreover, the NSF initiative in nanotechnology includes $\$ 20$ million to support studies of novel "nanobiostructures and processes at nanoscales, cells, nanobiotechnology, therapeutics, and diagnostics."

Other federal programs with biotechnology research components also are marked for increases or for initiatives of interest. For example, the USDA Agricultural Research Service budget request increases by $\$ 50$ million to $\$ 956$ million, while the USDA Cooperative State Research, Education, and Extension Service budget of $\$ 1,096$ million includes $\$ 150$ million for the National Research Initiative, a 26\% increase over FY 2000. Some of these funds are part of the joint USDA-DOE biobased products and bioenergy initiative.

The overall biological and environmental research budget request for DOE is $\$ 445$ million, a modest increase over the past year. Meanwhile, the Advanced Technology Program within the Commerce Department's National Institute of Standards and Technology (Gaithersburg, $\mathrm{MD})$ is slated for an increase of $\$ 31.8$ million to $\$ 175.5$ million. A portion of this R\&D program supports cooperative ventures between biotechnology companies and researchers at not-for-profit institutions.

The budget request also affects regulatory agencies that oversee parts of the biotechnology industry, including the Animal and Plant Health Inspection Service (APHIS) within USDA and the Food and Drug Administration (FDA; Rockville, MD). The APHIS budget request decreases modestly from the previous year to $\$ 645$ million. The FDA overall budget request of $\$ 1.391$ billion represents an increase of $13 \%$ over the past year. That total includes $\$ 203$ million in industry user fees and a request to add 501 staff members to the agency work force. The budget includes $\$ 42$ million for improvements in pre-market product reviews and $\$ 45$ million for increased post-market surveillance efforts.

Jeffrey L. Fox 